DOI $10.31489 / 2020 \mathrm{M} 3 / 86-95$

MSC 92D30

\author{
Evren Hincal $^{1,2}$, Bilgen Kaymakamzade ${ }^{1,2}$, Nezihal Gokbulut ${ }^{1,2}$ \\ ${ }^{1}$ Department of Mathematicts, Near East University, TRNC, Turkey \\ ${ }^{2}$ Mathematics Research Center, Near East University, TRNC, Turkey \\ (E-mail: evren.hincal@neu.edu.tr, bilgen.kaymakamzade@neu.edu.tr,nezihal.gokbulut@neu.edu.tr)
}

\title{
Basic reproduction number and effective reproduction number for North Cyprus for fighting Covid-19
}

\begin{abstract}
The aim of this paper is to show how North Cyprus fought with Covid-19 by using $R_{0}$ and $R_{t}$, as herd immunity. For that purpose, we used a SEIR model for basic reproduction number, $R_{0}$, and calculated $R_{t}$ values by using $R_{0}$ values. North Cyprus is the first country in Europe to free from Covid-19 epidemic. One of the most important reasons for this is that the government decided to tackle Covid-19 pandemic by using $R_{0}$ and $R_{t}$ daily. For $R_{0}$, we constructed a new SEIR model by using real data for North Cyprus. From March 11, 2020 to May 15, 2020, $R_{0}$ varies from 0.65 to 2.38 .
\end{abstract}

Keywords: Covid-19, Northern Cyprus, epidemics, mathematical model.

\section{Introduction}

Coronavirus is the virus that causes one of the most infectious diseases, Covid-19 (namely SARSCoV-2). This highly fatal disease began in December 2019, in Wuhan, China [1]. Disease has been named by the World Health Organization, after a new coronavirus discovered from an infected patient by Chinese Center for Disease Control and Prevention (CDC) [2]. In a susceptible population, the main route of the transmission for Covid-19 is through small droplets from an infected person to other people [3].

Symptoms of this disease are very similar with influenza, such as high fever, dry cough, tiredness. Intensity of symptoms can range from very mild to severe. Infected people may have many symptoms or no symptoms at all [4]. Many countries around the world have brought many restrictions to prevent the spread of the disease. These restrictions include closure of workplaces, shops, restaurants and airports [5].

Cyprus is the third largest island located in the Mediterranean region. In the North side of Cyprus, the population is approximately 374000, and consists mainly of Turkish Cypriots [6]. In Northern Cyprus, the SARS-CoV-2 outbreak started with patient zero on March 9, 2020 [7]. SARS-CoV-2 entered the Northern Cyprus through the routes of Germany and England [7]. Since then the government took many restrictions to prevent the spread of disease. On March 10, 2020 all of the schools, including universities, were closed till March 15, 2020. Then closure was extended till the end of semester. Afterwards, on March 15, 2020, all businesses except markets, pharmacies and gas stations were closed. With all these restrictions, partial curfew and closure of the airport were announced by councilof ministers.

For infectious diseases, mathematical models can be constructed in order to study the infectiousness of the disease. SEIR model is one type of the mathematical models that contains four main compartments which are $S, E, I$, and $R$. Here $S$ denotes susceptible, $E$ denotes exposed (infected but not yet infectious), $I$ denotes infectious and $R$ denotes recovered individuals in that population [8]. We constructed a new SEIR model in order to calculate $R_{0}$ and $R_{t}$ by using real data for North Cyprus [7].

The basic reproduction number, denoted by $R_{0}$, can be defined as the number of cases which are expected to occur on average in a homogeneous population as a result of infection by a single individual. The effective reproduction number, $R_{e}$, sometimes also denoted by $R_{t}$, is the number of people in a population who can be infected by an individual at any specific time. It changes as the population 
becomes increasingly immunized, either by individual immunity following infection or by vaccination, and also as people die $[9,10]$.

There are few differences between $R_{0}$ and $R_{t}$. The main difference is that in $R_{0}$ there are no immune individuals taken into account while in $R_{t}$ we count immune individuals as well. During an epidemic $R_{0}$ can not reflect the change of epidemic in time but $R_{t}$ can provide more information since it tracks the evolution of transmission. Another important difference is that $R_{0}$ works with daily cases. However, $R_{t}$ generally works with death ratios $[11,12]$.

Currently, a total of 30025 tests have been conducted resulting in 108 Covid-19 positive cases in Northern Cyprus, of whom no patients are left under treatment. There are no individuals under quarantine for 26 days due to the risk of carrying the Covid-19. As a result, 104 of patients have recovered and 4 deaths have occurred [7]. North Cyprus is the first European Country that has become Covid-19 free in 37 days [13]. In addition, no new cases were seen for 75 days.

In this paper, firstly we define the basic reproduction number, $R_{0}$, and the effective reproduction number, $R_{t}$, as herd immunity. Then, we define the method and formulas which we have used in order to calculate $R_{0}$ and $R_{t}$ values. With these values, we illustrate in figures the evolution of disease in North Cyprus. Lastly, we conclude our findings.

\section{The basic reproduction number}

An epidemiological definition of the basic reproduction number, denoted by $R_{0}$, is the expected number of secondary cases by a single individual who is infected in an entirely susceptible population $[14,15]$. Estimating $R_{0}$ values in an epidemic can be helpful in order to see the infectiousness of the disease. For that purpose we generally use mathematical modeling to find a formula for $R_{0}$ of an epidemic $[15,16]$.

Basic reproduction number is calculated by using the parameters of the mathematical model [17]. Biological, social behaviour, and environmental factors can affect the basic reproduction number [18]. However, immunization is not an effect for $R_{0}$, which may occur naturally or by vaccination [19].

When $R_{0}>1$, outbreak is expected to continue. We expect an outbreak to end if $R_{0}<1$ or in other words the number of infected individuals are expected to decrease $[18,20]$. Since $R_{0}<1$ means that each infected individual causes less than one new infection, this guarantees that the disease will die out under that circumstances [21]. Hence, we desire the value of $R_{0}$ to be less than 1 .

Basic reproduction numbers for the previous pandemics are given in Fig. 1. SARS-CoV-2 has an average value 2.65 during this pandemic if we compare with the other pandemics. If we check the Fig. 1, we can easily see that measles, HIV, or even influenza (Autumn 1918) are more infectious than SARS-CoV-2.

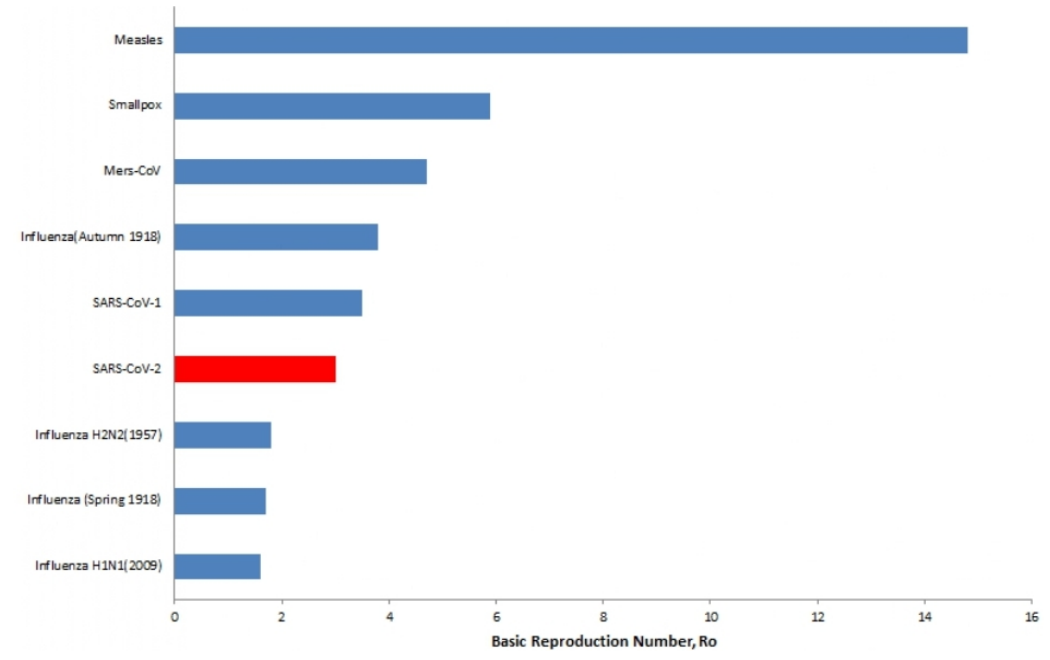

Figure 1. The basic reproduction numbers for pandemics comparing to SARS-Cov-2 (Covid-19) 


\section{The effective reproduction number}

The Effective Reproduction Number, $R_{t}$, can be defined as the real average number of secondary cases infected by primary cases per time [10]. As in $R_{0}, R_{t}<1$ means that epidemic will decline and the epidemic will spread if $R_{t}>1$ [10]. In this paper, we will use the effective reproduction number as herd immunity.

When most of the population gain immunity to an infectious disease, this provides indirect protection, namely herd immunity, to those who don't have immunity to that disease. In other words, in a population, the greater the number of immune people means the lower likelihood that a susceptible individual will be infected [22]. There are two ways for gaining herd immunity; vaccines and infection. Since the vaccine of SARS-CoV-2 has not been found yet, we can analyze herd immunity idea only for infection [23].

There is a threshold that must be reached in order to say that the population has gained herd immunity. This threshold is called herd immunity threshold which is the percentage of the population that must be immune by getting infected [22]. Herd immunity threshold changes from disease to disease. The proportion of the population that needs to gain immunity to the disease to stop the spreading increase as the infectiousness of the disease increase [23].

In this paper, we calculate the effective reproduction number, $R_{t}$, as herd immunity. We attempt to analyze the herd immunity idea for Northern Cyprus.

Calculating the basic reproduction number and effective reproduction number

In order to calculate the basic reproduction number in Northern Cyprus we use a basic SEIR model where $S$ is susceptible, $E$ is exposed, $I$ is infectious and $R$ is the recovery compartment. This model was first introduced by William Ogilvy Kermack and Anderson Gray McKendrick in 1927.

In this paper, herd immunity, $R_{t}$, is calculated by the following formula

$$
R_{t}=1-\frac{1}{R_{0}}
$$

where $R_{0}$ is the basic reproduction number.

We construct the following model for Covid-19

$$
\begin{array}{r}
\frac{d S}{d t}=\pi-\lambda S, \\
\frac{d E}{d t}=\lambda S-\left(\theta_{1}+\theta_{2}\right) E, \\
\frac{d Q}{d t}=\theta_{1} E-\left(\delta_{1}+\theta_{3}\right) Q, \\
\frac{d I_{1}}{d t}=\theta_{2} E+\theta_{3} Q-\left(\delta_{2}+\omega+\theta_{4}+\alpha_{1}\right) I_{1}, \\
\frac{d I_{2}}{d t}=\theta_{4} I_{1}-\left(\Phi+\alpha_{2}+\delta_{3}\right) I_{2}, \\
\frac{d H}{d t}=\omega I_{1}+\Phi I_{2}-\left(\delta_{4}+\alpha_{3}\right) H, \\
\frac{d R}{d t}=\delta_{1} Q+\delta_{2} I_{1}+\delta_{3} I_{2}+\delta_{4} H,
\end{array}
$$

called a SEIR model with seven compartments which are explained in Table 1. By using this model and system, we calculated $R_{0}$ values for North Cyprus with real data. The formula for $R_{0}$ can be obtained by using the next generation matrix method. Then, with calculated $R_{0}$ values, we can find $R_{t}$ values using formula (1). 
The value of $R_{0}$ is calculated as

$$
R_{0}=\frac{\left(\left(\left(b_{1} \beta \tau_{1}+\beta \tau_{2} \theta_{3}\right) \theta_{1}+\beta \tau_{2} k_{2} \theta_{2}\right) k_{3}+\omega \beta \tau_{4}\left(\theta_{2} k_{2}+\theta_{3} \theta_{1}\right)\right) b_{2}+\theta_{4}\left(\beta \tau_{4} \varphi+\beta \tau_{3} k_{3}\right)\left(\theta_{2} k_{2}+\theta_{3} \theta_{1}\right)}{k_{1} k_{2} k_{3} b_{1} b_{2}},
$$

where the variables and parameters of the model are described in Table 1 and Table 2, respectively. Here

$$
k_{1}=\theta_{1}+\theta_{2}, k_{2}=\delta_{1}+\theta_{3}, k_{3}=\delta_{4}+\alpha_{3}, b_{1}=\delta_{2}+\omega+\theta_{4}+\alpha_{1}, b_{2}=\varphi+\alpha_{2}+\delta_{3}
$$

Variables for the model

\begin{tabular}{|c|c|}
\hline Variables & Descriptions \\
\hline$N$ & Total population of humans \\
\hline$S$ & Susceptible humans at the risk of having COVID-19 infection \\
\hline$E$ & Exposed humans \\
\hline$I_{1}$ & Infected humans with moderate infection \\
\hline$I_{2}$ & Infected humans with severe infection \\
\hline$Q$ & Human population under quarantine / isolation \\
\hline$H$ & Hospitalized humans \\
\hline$R$ & Recovered humans \\
\hline
\end{tabular}

Table 1

Table 2

\section{Parameters for the model and basic reproduction number}

\begin{tabular}{|c|c|}
\hline Parameters & Descriptions \\
\hline$\pi$ & Recruitment rate \\
\hline$\beta$ & Transmission rate \\
\hline$\tau_{i}(i=1,2,3,4)$ & Parameters for increase / decrease on infectiousness in humans \\
\hline$\theta_{i}(i=1,2,3,4)$ & Progression rates \\
\hline$\omega$ & Hospitalization rate from $I_{1}$ class \\
\hline$\phi$ & Hospitalization rate from $I_{2}$ class \\
\hline$\alpha_{i}(i=1,2,3)$ & Disease induced death rates \\
\hline$\delta_{i}$ & Recovery rates \\
\hline
\end{tabular}

A formula (2) for $R_{0}$ is obtained by using the method which needs next generation matrix where finitely many distinct categories of individuals are introduced in a population. The method that uses next generation matrix for calculating $R_{0}$ was introduced by Diekmann et al. (1990) and van den Driessche and Watmough (2002) [24]. This method needs two matrices which can be obtained from the mathematical model. One matrix includes new infections of the disease taken from the system while the other matrix consists of the rest of the system [24,25].

As we can see from Figure 2, while calculating $R_{0}$ and $R_{t}$ values, we used daily cases between the dates March 11, 2020 and May 15, 2020. We can observe that after approximately April 27, 2020, $R_{0}$ value decreased below one. This means that disease is not infectious anymore in TRNC under taken restrictions, after that time.

On the other hand, if we look at the $R_{t}$ values which were calculated by formula (1), we see that it is below one from the beginning. So, we can not make any comment by using $R_{t}$ for North Cyprus. 

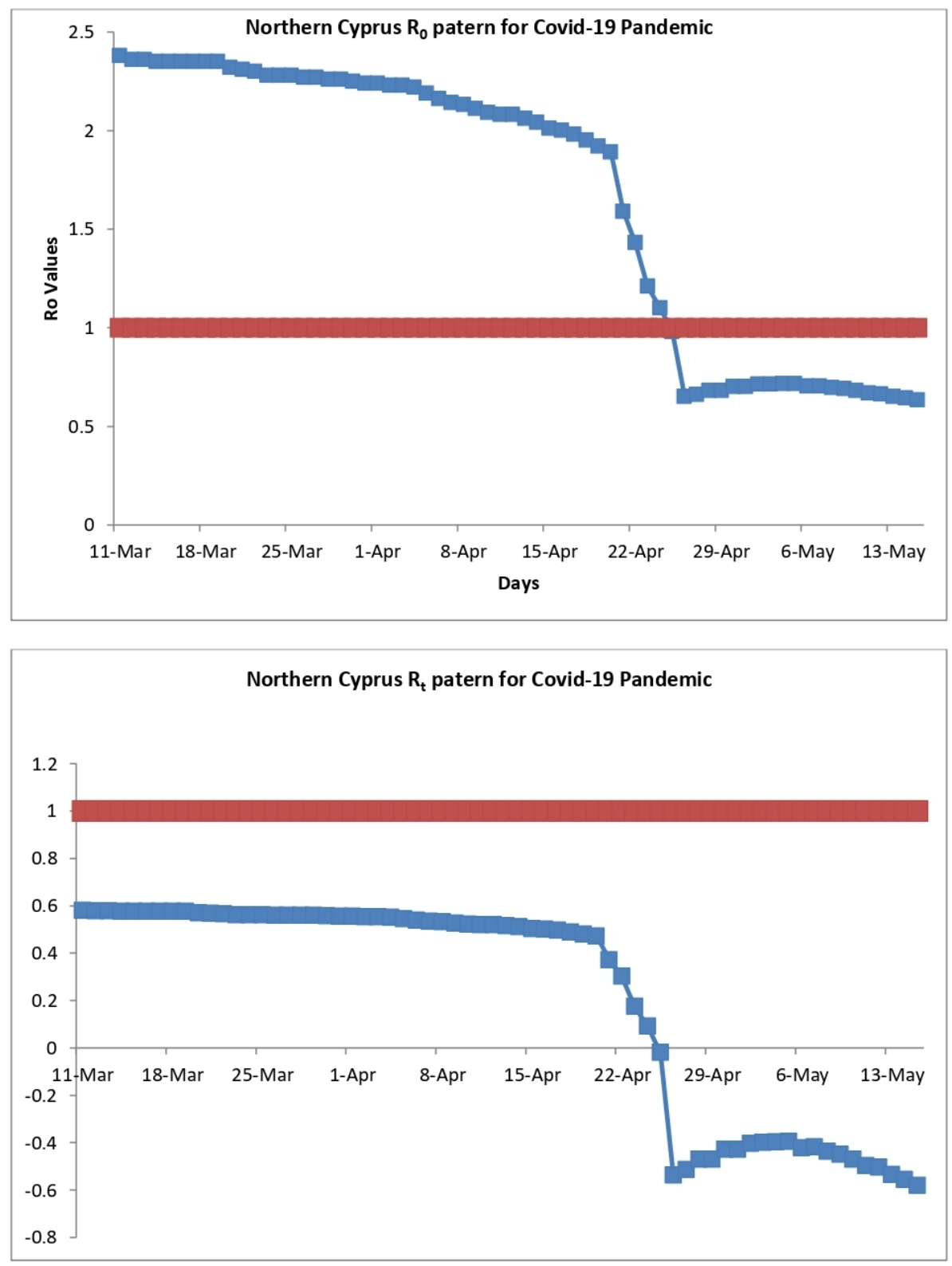

Figure 2. $R_{0}$ and $R_{t}$ values from March 11, 2020 to May 15, 2020

\section{Conclusions}

Tackling of Covid-19 in North Cyprus has been compared with the other European countries. With using the model, we calculated the basic reproduction number that secondary cases of new infectious for Covid-19. Then we compared the infectiousness of the Covid-19 with the other pandemics, which can be seen in Figure 1.

Some of countries used effective reproduction number during the SARS-CoV-2 pandemic. In Figure 2 , we gave two graphs that are showing the infectiousness in North Cyprus with using $R_{0}$ and $R_{t}$. Between April 17, 2020 - July 1, 2020 there were no new Covid-19 cases in North Cyprus. It can be seen in the Figure 2 that this was what we assumed for the progression of the disease in North Cyprus by using $R_{0}$ values that we have obtained from the formula (2).

Furthermore, we have monitored Covid-19 pandemic in North Cyprus with $R_{t}$ as herd immunity. The second graph in Figure 2 illustrates that $R_{t}$ values are less than one which shows us that there 
was no pandemic in North Cyprus. Although, both figures have similar behaviour, Figure 2 shows that $R_{0}$ is more effective than $R_{t}$. However, we can not generalize this result.

In Figure 3, we can see that the North Cyprus has the lowest death rate with highest recovery in Europe. Furthermore, North Cyprus is the leading country in Europe that it has almost 80000 tests around 1000000 population. As a result, we can say that North Cyprus has reached zero at the case of Covid-19 in 37 days.
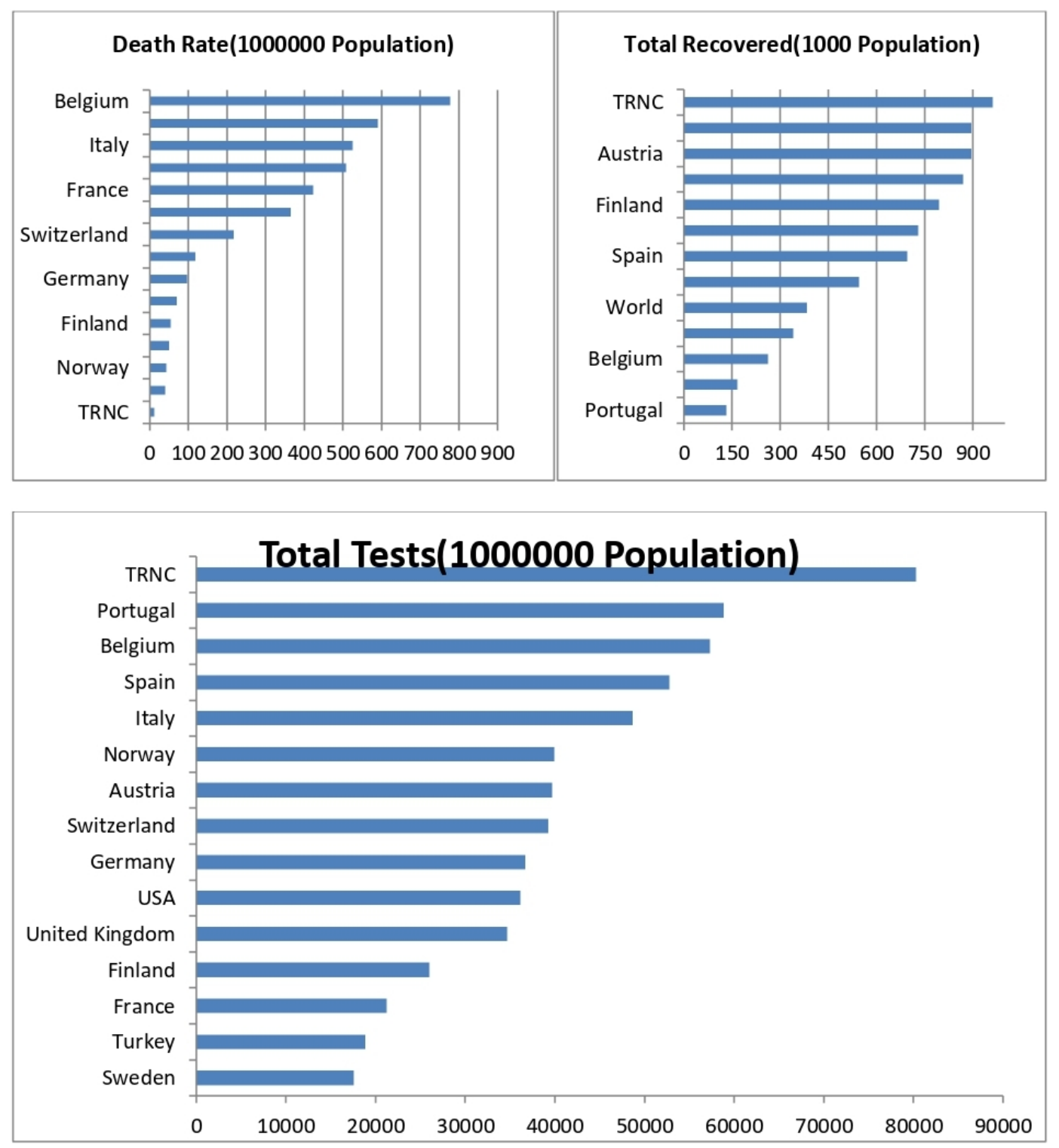

Figure 3. Comparison of North Cyprus with some other countries and world data between March 11, 2020 and May 15, 2020

Acknowledgements

The publication has been prepared with the support of Mathematical Research Center, Near East University, TRNC. 
References

1 Pham H. On Estimating the Number of Deaths Related to Covid-19 / H. Pham // Mathematics. - 2020. - 8. - P. 655.

2 Chen. N. Epidemiological and clinical characteristics of 99 cases of 2019 novel coronavirus pneumonia in Wuhan, China: a descriptive study/N.Chen, M.Zhou, X.Dong, J.Qu, F.Gong, Y.Han, Y.Qiu, J.Wang, Y.Liu, Y.Wei, J.Xia, T.Yu, H.Zhang, L.Zhang // Lancet. - 2020. 395. - P. 507-513.

3 Ciotti, M. COVID-19 Outbreak: An Overview / M.Ciotti, S.Angeletti, M. Minieri, M. Giovannetti, D. Benvenuto, S. Pascarella, C.Sagnelli, M. Bianchi, S.Bernardini, \& M.Ciccozzi // Chemotherapy. - 2020. - 64. - P. 215-223.

4 Coronavirus disease 2019 (COVID-19). Retrieved from https: // www.mayoclinic.org/diseasesconditions / coronavirus/symptoms-causes/syc-20479963.

5 Chinazzi, M. The effect of travel restrictions on the spread of the 2019 novel coronavirus (COVID19) outbreak / M. Chinazzi, J.T. Davis, M. Ajelli, C. Gioannini, M. Litvinova, S. Merler, A.P. Piontti K. Mu, L. Rossi, K. Sun, C. Viboud, X. Xiong, H. Yu, M.E. Halloran, I.M. Longini, \& A.Vespignani // Science. - 2020. - 368. - P. 395-400.

6 Kliot N. The political landscape of partition: The case of Cyprus / N. Kliot, Y. Mansfield // Political Geography. - 1997. - 16. - P. 495-521.

7 Turkish Republic of Northern Cyprus, Ministry of Health. [Electronic resource]. - Access mode: http: // saglik.gov.ct.tr.

8 Grant A. Dynamics of COVID-19 epidemics: SEIR models underestimate peak infection rates and overestimate epidemic duration [Electronic resource] / A. Grant. - Access mode: https: // doi.org/10.1101/2020.04.02.20050674.

9 Farrington C.P. Estimation of effective reproduction numbers for infectious diseases using serological survey data / C.P. Farrington, H.J. Whitaker // Biostatistics. - 2003. - 4. - P. 621632.

10 Nishiura $\mathrm{H}$. The effective reproduction number as a prelude to statistical estimation of timedependent epidemic trends / H. Nishiura, G. Chowel // Mathematical and Statistical Estimation Approaches in Epidemiology. - 2009. 103-121.

11 Kwok K.O. Herd immunity - estimating the level required to halt the COVID-19 epidemics in affected countries / K.O. Kwok, L. Lai, W.I. Wei, S.Y.S. Wong, J.W.T. Tang // Journal of Infection. - 2020. - 80. - P. e32-e33.

12 Ng T. Spatially Adjusted Time-varying reproductive numbers: understanding the geographical expansion of urban dengue outbreaks / T. Ng, T. Wen // Scientific Reports. - 2019. - 9. 19172.

13 Coronavirus disease (COVID-19) pandemic [Electronic resource]. - Access mode: https: // www.who.int /emergencies/diseases/novel-coronavirus-2019.

14 Cintron-Arias A. The estimation of the effective reproductive number from disease outbreak data / A. Cintron-Arias, C. Castillo-Chavez, L.M.A. Bettencourt, A.L. Lloyd, H.T. Banks // Mathematical Biosciences and Engineering. - 2009. - 6. - P. 261-282.

15 Driessche P. Reproduction numbers of infectious disease models / P. Driessche / Infectious Disease Modelling. - 2017. - 2. - P. 288-303.

16 Nishiura H. Pros and cons of estimating the reproduction number from early epidemic growth rate of influenza A (H1N1) 2009 / H. Nishiura, G. Chowell, M. Safan, \& C.Castillo-Chavez // Theoretical Biology and Medical Modelling. - 2010. - 7. - 1.

17 Allen L.J.S. The basic reproduction number in some discrete-time epidemic models / L.J.S. Allen, P. Driessche // Journal of Difference Equations and Applications. - 2008. - 14. - P. 1127-1147. 
18 Delamater P.L. Complexity of the basic reproduction number $R_{0} /$ P.L. Delamater, E.J. Street, T.F. Leslie, Y.T. Yang, K.H. Jacobsen // Emerging Infectious Diseases. - 2019. - 25. - P. 1-4.

19 Bell D.J. Basic reproduction number / D.J. Bell, C.M. Moore, et al. [Electronic resource]. Access mode: https: // radiopaedia.org/articles/basic-reproduction-number-1.

20 Sato K. Basic reproduction number of SEIRS model on regular lattice / K. Sato // Mathematical Biosciences and Engineering. - 2019. - 16. - P. 6708-6727.

21 Ramirez V.B. What is $R_{0}$ ? Gauging contagious infections / V.B. Ramirez. [Electronic resource]. - Access mode: https: // www.healthline.com/health/r-nought-reproduction-number.

22 Barratt H. Epidemic theory (effective and basic reproduction numbers, epidemic thresholds) and techniques for analysis of infectious disease data [Electronic resource] / H. Barratt, M. Kirwan, S.Shantikumar. - Access mode: https: // www.healthknowledge.org.uk/public-health-textbook /research-methods /1a-epidemiology/epidemic-theory.

23 Herd immunity and Covid-19 (coronavirus): What you need to know. Article Number 20486808. [Electronic resource]. - Access mode: https: // www.mayoclinic.org.

24 Diekmann O. The construction of next-generation matrices for compartmental epidemic models / O. Diekmann, J.A.P. Heesterbeek, M.G. Roberts // Journal of the Royal Society Interface. - 2010. - 7. - P. 873-885.

25 Yang H.M. The basic reproduction number obtained from Jacobian and next generation matrices - A case study of dengue transmission modelling / H.M. Yang // Biosystems. - 2014. - 126. - P. 52-75.

Э. Хинжал, Б. Каймакамзаде, Незихал Гокбулут

\title{
Ковид-19 пандемиясымен күресу үшін Солтүстік Кипрдің репродукциясының базалық нөмірі және репродукциясының тиімді нөмірі
}

\begin{abstract}
Мақаланың мақсаты - ұжымдық иммунитет ретінде R0 және Rt қолдану арқылы Солтүстік Кипр Covid-19 пандемиясымен қалай күрескенін көрсету. Осы мақсатта R0 мәндерін қолдану арқылы Rt мәндері есептелді және R0 базалық нөмірін ойнату үшін SEIR моделі қолданылған. Солтүстік Кипр - Ковид-19 эпидемиясынан айыққан Еуропа елдері ішінен алғашқы ел болып табылады. Мұның маңызды себептерінің бірі - үкіметтің күнделікті R0 және Rt қолданып, Ковид-19 пандемиясымен күресу туралы шешім қабылдауы. Солтүстік Кипр үшін нақты мәліметтерді қолданып, R0 үшін SEIR жаңа моделін құрастырды. 2020 жылдың 11 наурызынан бастап 2020 жылдың 15 мамырына дейін R0 мәні 0,65- тен 2,38-ге дейін ауытқып тұрды.
\end{abstract}

Кілт сөздер: Ковид-19, Солтүстік Кипр, эпидемиялар, математикалық модель.

Э. Хинжал, Б. Каймакамзаде, Незихал Гокбулут

\section{Базовый номер репродукции и эффективный номер репродукции Северного Кипра для борьбы с Ковид-19}

Цель данной статьи - показать, как Северный Кипр боролся с Covid-19, используя $R_{0}$ и $R_{t}$, в качестве коллективного иммунитета. Для этого авторами использована модель SEIR для базового номера воспроизведения, $R_{0}$, и вычисление значения $R_{t}$, используя значения $R_{0}$. Северный Кипр является первой страной в Европе, которая избавилась от эпидемии Ковид-19. Одна из наиболее важных причин этого заключается в том, что правительство решило бороться с пандемией Covid-19, используя 
ежедневные $R_{0}$ и $R_{t}$. Для $R_{0}$ нами построена новая модель SEIR с использованием реальных данных для Северного Кипра. С 11 марта 2020 г. по 15 мая 2020 г. уровень $R_{0}$ в этой стране колеблется в пределах от 0,65 до 2,38.

Ключевые слова: Ковид-19, Северный Кипр, эпидемии, математическая модель.

\section{References}

1 Pham, H. (2020). On Estimating the Number of Deaths Related to Covid-19. Mathematics, Vol. 8, 655 .

2 Chen, N., Zhou, M., Dong, X., Qu, J., Gong, F., Han, Y., Qiu, Y., Wang, J., Liu, Y., Wei, Y., Xia, J., Yu, T., Zhang, H. \& Zhang, L. (2020). Epidemiological and clinical characteristics of 99 cases of 2019 novel coronavirus pneumonia in Wuhan, China: a descriptive study. Lancet, Vol. 395, $507-513$.

3 Ciotti, M., Angeletti, S., Minieri, M., Giovannetti, M.,

Benvenuto, D., Pascarella, S., Sagnelli, C., Bianchi, M., Bernardini, S. \& Ciccozzi M. (2020). COVID-19 Outbreak: An Overview. Chemotherapy, Vol. 64, 215-223.

4 Coronavirus disease 2019 (COVID-19). mayoclinic.org. Retrieved from https://www. mayoclinic.org/ diseases-conditions/coronavirus/symptoms-causes/syc-20479963.

5 Chinazzi, M., Davis, J.T., Ajelli, M., Gioannini, C., Litvinova, M., Merler, S., Piontti, A.P., Mu, K., Rossi, L., Sun, K., Viboud, C., Xiong, X., Yu, H., Halloran, M.E., Longini, I.M. \& Vespignani, A. (2020). The effect of travel restrictions on the spread of the 2019 novel coronavirus (COVID-19) outbreak. Science, Vol. 368, 395-400.

6 Kliot, N. \& Mansfield, Y. (1997). The political landscape of partition: The case of Cyprus. Political Geography, Vol. 16, 495-521.

7 Turkish Republic of Northern Cyprus, Ministry of Health. saglik.gov. Retrieved from http://saglik. gov.ct.tr.

8 Grant A. Dynamics of COVID-19 epidemics: SEIR models underestimate peak infection rates and overestimate epidemic duration. doi.org. Retrieved from https://doi.org/10.1101/2020.04.02. 20050674.

9 Farrington, C.P. \& Whitaker, H.J. (2003). Estimation of effective reproduction numbers for infectious diseases using serological survey data. Biostatistics, Vol. 4, 621-632.

10 Nishiura, H. \& Chowel, G. (2009). The effective reproduction number as a prelude to statistical estimation of time-dependent epidemic trends. Mathematical and Statistical Estimation Approaches in Epidemiology, 103-121.

11 Kwok, K.O., Lai, L., Wei, W.I., Wong S.Y.S. \& Tang, J.W.T. (2020). Herd immunity - estimating the level required to halt the COVID-19 epidemics in affected countries. Journal of Infection, Vol. 80, e32-e33.

12 Ng, T. \& Wen, T. (2019). Spatially Adjusted Time-varying reproductive numbers: understanding the geographical expansion of urban dengue outbreaks. Scientific Reports, Vol. 9, 19172.

13 Coronavirus disease (COVID-19) pandemic. who.int. Retrieved from https: //www.who. int/emergencies/ diseases/novel-coronavirus-2019.

14 Cintron-Arias, A., Castillo-Chavez, C., Bettencourt, L.M.A., Lloyd, A.L. \& Banks, H.T. (2009). The estimation of the effective reproductive number from disease outbreak data. Mathematical Biosciences and Engineering, Vol. 6, 261-282.

15 Driessche, P. (2017). Reproduction numbers of infectious disease models. Infectious Disease Modelling, Vol. 2, 288-303. 
16 Nishiura, H., Chowell, G., Safan, M. \& Castillo-Chavez, C. (2010). Pros and cons of estimating the reproduction number from early epidemic growth rate of influenza A (H1N1) 2009. Theoretical Biology and Medical Modelling, Vol. 7, 1.

17 Allen, L.J.S. \& Driessche, P. (2008). The basic reproduction number in some discrete-time epidemic models. Journal of Difference Equations and Applications, Vol. 14, 1127-1147.

18 Delamater, P.L., Street, E.J., Leslie, T.F., Yang, Y.T. \& Jacobsen, K.H. (2019). Complexity of the basic reproduction number $R_{0}$. Emerging Infectious Diseases, Vol. 25, 1-4.

19 Bell, D.J., Moore, C.M., et al. Basic reproduction number. radiopaedia.org. Retrieved from https: //radiopaedia.org/articles/basic-reproduction-number-1.

20 Sato, K. (2019). Basic reproduction number of SEIRS model on regular lattice. Mathematical Biosciences and Engineering, Vol. 16, 6708-6727.

21 Ramirez, V.B. What is $R_{0}$ ? Gauging contagious infections. healthline.com. Retrieved from https: //www.healthline.com/health/r-nought-reproduction-number.

22 Barratt, H., Kirwan, M. \& Shantikumar, S. Epidemic theory (effective and basic reproduction numbers, epidemic thresholds) and techniques for analysis of infectious disease data. healthknowledge.org. Retrieved from https://www.healthknowledge.org.uk/public-health-textbook/researchmethods /1a-epidemiology/epidemic-theory.

23 Herd immunity and Covid-19 (coronavirus): What you need to know. Article Number 20486808. mayoclinic.org. Retrieved from https://www.mayoclinic.org.

24 Diekmann, O., Heesterbeek, J.A.P. \& Roberts, M.G. (2010). The construction of next-generation matrices for compartmental epidemic models. Journal of the Royal Society Interface, Vol. 7, 873-885.

25 Yang, H.M. (2014). The basic reproduction number obtained from Jacobian and next generation matrices - A case study of dengue transmission modelling. Biosystems, Vol. 126, 52-75. 